\title{
CONTRIBUTIONS TO THE
} JAPANESE ASCIDIAN FAUNA XXX. FURTHER NOTES ON JAPANESE CLAVELINIDS-

\section{$\operatorname{AUTHOR(S):~}$}

Tokioka, Takasi; Nishikawa, Teruaki

\section{CITATION:}

Tokioka, Takasi ...[et al]. CONTRIBUTIONS TO THE JAPANESE ASCIDIAN FAUNA XXX. FURTHER NOTES ON JAPANESE CLAVELINIDS-. PUBLICATIONS OF THE SETO MARINE BIOLOGICAL LABORATORY 1976, 23(3-5): 341-350

\section{ISSUE DATE:}

1976-10-30

URL:

http://hdl.handle.net/2433/175932

RIGHT: 


\title{
GONTRIBUTIONS TO THE JAPANESE ASCIDIAN FAUNA XXX. FURTHER NOTES ON JAPANESE GLAVELINIDS ${ }^{1)}$
}

\author{
TAKasi TOKIOKA and Teruaki NISHIKAWA \\ Seto Marine Biological Laboratory
}

With Text-figures $1-4$

Three more materials of Japanese clavelinids came into our hand after the Japanese clavelinids known so far had been reviewed (Nishikawa and Tokioka, 1976), two colonies collected from Sagami Bay and preserved at the Biological Laboratory of the Imperial Household, a single colony collected by Mr. Y. Yanagisawa from the Bonin Islands and a single colony collected by Prof. T. Kikuchi from the Ariake Sea, Kyusyu Island. The first included two species, Clavelina elegans (Oka) and a new species, the last was identified with $C$. elegans, while the second seemed to belong to C. molluccensis (Sluiter) that had not yet been recorded from the Japanese waters. As the range of morphological variations in C. elegans is known but still very insufficiently, it is considered significant to record some features of these two more colonies again in the present paper. In addition to this, a brief description is given as to $C$. molluccensis to confirm the identification and a full description is made on the new species of Clavelina, to which the name of viola is proposed by us for its characteristic colouration when alive.

Before going further, we wish to express our gratitude for the privilege of examining the specimens of the Biological Laboratory of the Imperial Household and also our hearty thanks to Prof. T. Kikuchi of the Amakusa Marine Biological Laboratory of Kyusyu University and to Mr. Y. Yanagisawa, a graduate student at our laboratory, for their generosity in offering those interesting specimens to our examination.

\section{Clavelina elegans (Oka, 1927)}

(Figs. 1-2)

Nishikawa and Tokioka (1976): Publ. Seto Mar. Biol. Lab., vol. 23, nos. 1/2, 68-73, figs. 3-5.

Material: Proto. No. 997 (TNo. 864) in the Biological Laboratory of the Imperial Household, a colony carrying two zooids and a single detached zooid, collected on March 13, 1971, $3.5 \mathrm{~km}$ wsw off Zyogasima in Sagami Bay, 93-99 m deep. A colony

1) Contributions from the Seto Marine Biological Laboratory, No. 630.

Publ. Seto Mar. Biol. Lab., XXIII (3/5), 341-350, 1976.

(Article 24) 
consisting of 25 zooids, collected by Kikuchi on August 1, 1966 from a rocky reef around Tûzisima Island, Amakusa.

Colony: In both colonies, zooidal tests are issued from the common basal mass. In the colony from Sagami Bay, the posterior portion of the abdomen is partly held in the common basal mass in the contracted state, while the common basal mass of the

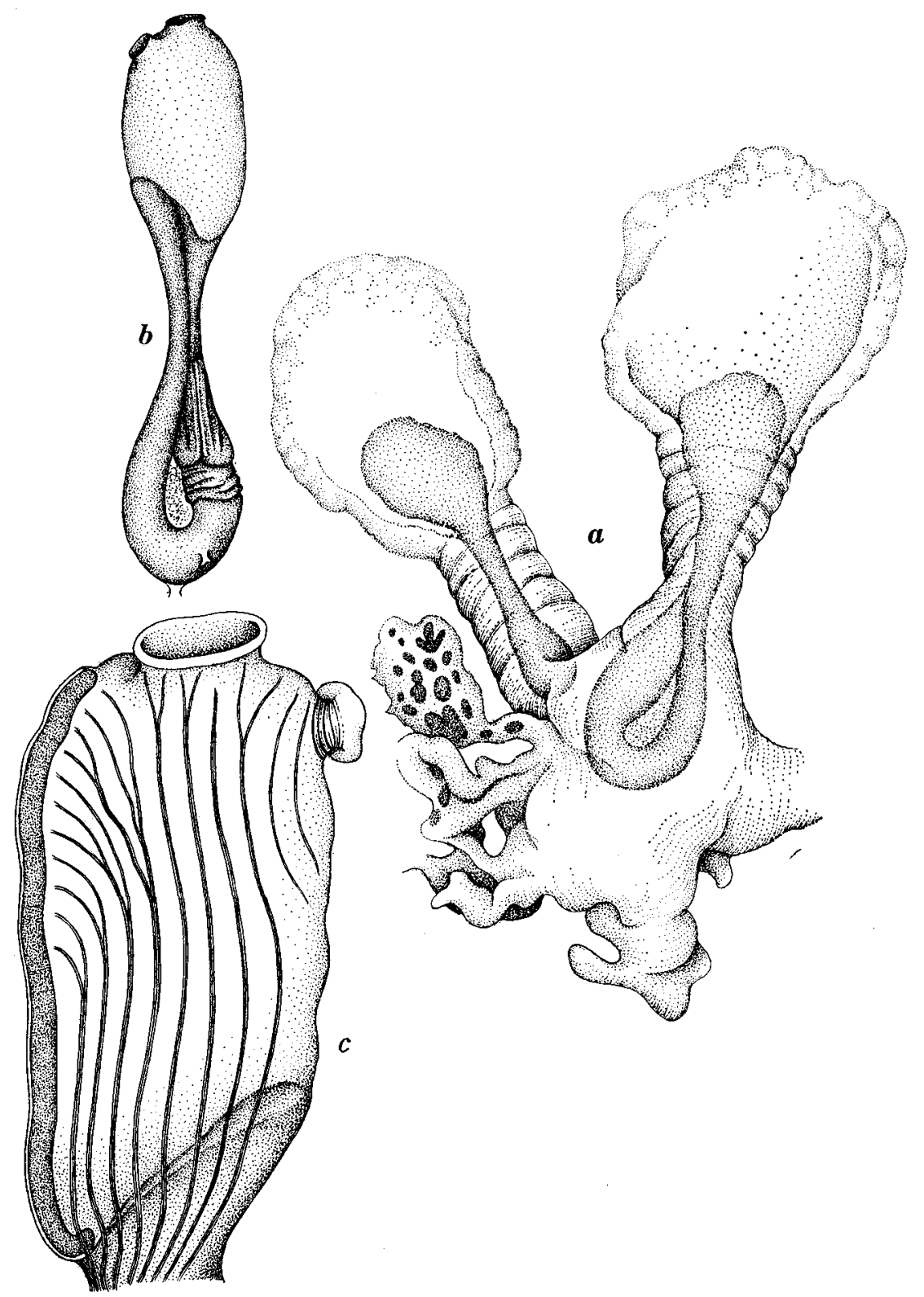

Fig. 1. Clavelina elegans (Oka), colony from Sagami Bay. a, two zooids issued from common basal mass. b, zooid, right side. c, thorax, left side. 
colony from Amakusa assumes a kind of fasciated appearance. Zooidal tests are 23-27 $\mathrm{mm}$ in the colony from Sagami Bay. The test is very soft and fragile in the distal half somewhat expanded and including the thorax when alive, but rather hard in the proximal half; and the common basal mass or the common stalk in the colony from Amakusa is further harder. It is colourless and transparent in the distal half of respective zooidal tests, but becomes less transparent and whitish proximally and the common basal mass or the stalk is whitish and translucent or partly quite opaque. A number of white bodies may be found in some prominences issued from the basal mass (Fig. 1, a). The field notes by Prof. Kikuchi show that the zooids of the living colony was cobalt blue and quite transparent. Actually, a purplish colouration remains still faintly all over the thrax and rather deeply on the dorsal side of and around the base of the branchial siphon.

Zooid: Mantle bodies in contracted states are 8.0 to $14.5 \mathrm{~mm}$ long and $12.0 \mathrm{~mm}$ on an average in the colony from Amakusa, but only $6.3 \mathrm{~mm}$ long in the colony from Sagami Bay; the thorax is nearly as long as the abdomen in the latter, but shorter than the abdomen in the former. In the living colony, the mantle body of extended zooids may be over $20 \mathrm{~mm}$ in length, with about $10 \mathrm{~mm}$ long thorax, as suggested by the size of respective zooidal tests.

The thoracic musculature consists of 10 to a dozen longitudinal muscles which are joined one another ventrally to form a pair of strong ventral muscle bands on the abdomen. These longitudinal muscles, at least some of them, may be oblique according to the state of contraction caused by themselves and also by the abdominal muscle bands. Further, they are classified as follows:

Endostylar muscles (E) - muscles ending anteriorly towards the endostyle,

Branchial muscles (B)-muscles ending anteriorly in the range between the anterior end of the endostyle and the ventral side of the dorsal ganglion,

Dorsal muscles (D)-muscles ending anteriorly dorsal to the dorsal side of the dorsal ganglion.

For instance, the muscle formula of the thorax is $4 \mathrm{E} \cdot 4 \mathrm{~B} \cdot 2 \mathrm{D}=10$ in the most extended thorax from the colony from Sagami Bay, while $3 \mathrm{E} \cdot 6 \mathrm{~B} \cdot 3 \mathrm{D}=12$ and $3 \mathrm{E} \cdot 7 \mathrm{~B} \cdot 3 \mathrm{D}=13$ on the left and right sides respectively of a thorax from the colony from Amakusa. Generally, more thoracic muscles are recorded on the zooids of the colony from Amakusa. As all these muscles are generally furcate anteriorly and branching may occur much posteriorly, the number of muscles may be considerably greater when they are counted at some anterior level of the thorax. Seventeen to 18 stigmatal rows in examined zooids of the colony from Amakusa, while 24(left)-26(right) rows in a zooid of the colony from Sagami Bay; stigmata 50 to 60 in each row. About 15 tentacles including larger and smaller ones alternating rather regularly, but attaining 20 to two dozens when minute ones are included. The ciliated groove is represented by a longitudinal slit. The incubatory pouch is well defined in zooids of the colony from Amakusa, extending posteriorly to the anterior quarter of the abdomen and containing more than 20 embryos and fertilized eggs. 

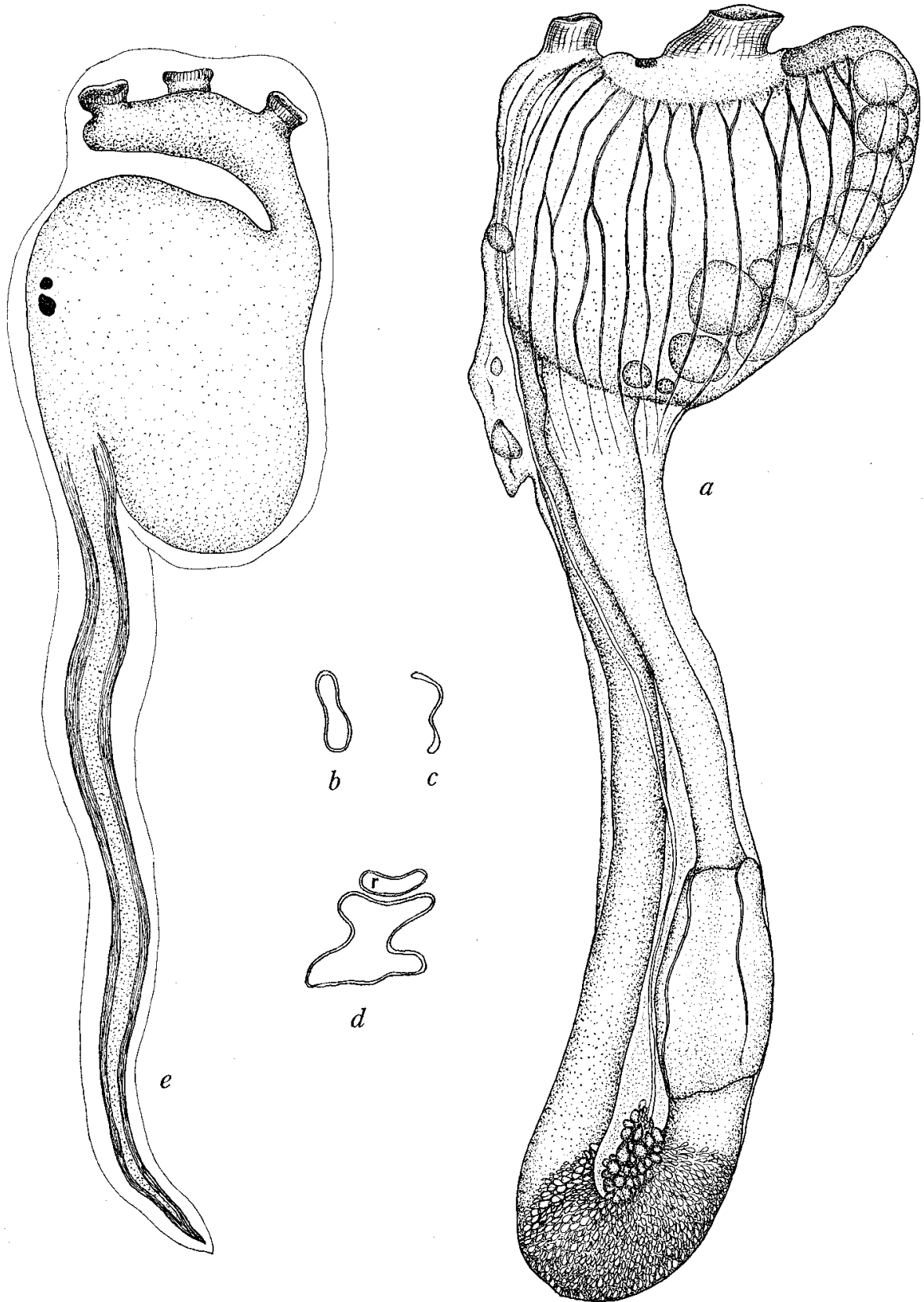

Fig. 2. Clavelina elegans (Oka), colony from Amakusa. a, zooid with extended abdomen, right side. $\mathbf{b}-\mathbf{c}$, ciliated grooves. $d$, section of stomach. e, larva. 
The stomach is provided with a few rather distinct plications (Fig. 2, d). Its situation seems to vary considerably according to the degree of contraction of the abdominal muscle bands and the developmental state of the gonad. A strong contraction in the anterior half of the muscle band will bring the stomach anteriorly, while a contraction near the posterior end of the muscle band will draw the stomach towards the rear end of the abdomen. On the other side, well developed gonadal mass will keep the distance between the pyloric end of the stomach and the rear end of the intestinal loop against a strong contraction. Thus, the stomach is sited around the middle of the abdomen in an examined immature zooid of the colony from Sagami Bay and also in some zooids with fully matured gonads from the Amakusa colony. In a zooid from the Amakusa colony, however, the stomach is located much posteriorly (Fig. 2, a), probably the abdomen might be fixed in a fully extended state. To confirm these points, it is urged to examine some live specimens of this species.

The trunk of larvac is up to $900 \mu$ in length, the anterior protuberance supporting three attachment processes is formed distinctly (Fig. 2, e).

Remarks: The formula of the thoracic muscles in the present colonies, especially in the colony from Sagami Bay, conforms well to that of the neotype, $4 \mathrm{E} \cdot 4 \mathrm{~B} \cdot 2 \mathrm{D}=10$ (see Nishikawa and Tokioka 1976; fig. 4, B).

\section{Clavelina viola $\mathrm{n} . \mathrm{sp}$.}

(Fig. 3)

Holotype: Proto. No. 996 (TNo. 863) in the Biological Laboratory of the Imperial Household, a large colony consisting of 164 zooids supported on a $10 \mathrm{~cm} \times 2 \mathrm{~cm}$ common basal mass composed of complicatedly branched and entangled stolons, collected in Sagami Bay, $2 \mathrm{~km}$ wnw off Kamegisyo Reef, 40-60 m deep, on January 26, 1970; with a colour transparency of the live colony.

Colony: Respective zooids are issued from the stolon strictly separately, no fusion occurring between the zooidal tests. Larger zooidal tests may attain $45 \mathrm{~mm}$ in length and $9 \mathrm{~mm}$ in the greatest width, the peduncular portion that is defined as the basal portion of the zooidal test posterior to the posterior end of the mantle body of the zooid is rather long, reaching up to $19 \mathrm{~mm}$ in length.

Zooid: Larger mantle bodies are about $20 \mathrm{~mm}$ long and the thorax is as long as the abdomen in a contracted state. The postabdominal vascular vessel is very prominent (Fig. 3, b). The colouration of live zooids is unique; the thorax is faintly purplish, but darker near the posterior margin and in the siphonal area where a prominent deep purplish pigmentation is extending from the dorsal side of the atrial siphon onto each lateral side to embrace an area coloured yellow between both apertures. In addition to this, a dark purplish round spot and a ' 1 -shaped patch of the same colouration are found respectively at the anterior end of the endostyle and above the dorsal ganglion (Fig. 3, c and d). The abdomen is wholly milky white but the stomach that is rather grayish. 
The atrial siphon is situated slightly anterior to the branchial (Fig. 3, b and c), both apertures are margined plainly. Main thoracic muscles are longitudinal, the muscle formula is $7 \mathrm{E} \cdot 3 \mathrm{~B} \cdot 4 \mathrm{D}=14$ on the right and $6 \mathrm{E} \cdot 4 \mathrm{~B} \cdot 3 \mathrm{D}=13$ on the left side in an examined zooid or $7 \mathrm{E} \cdot 6 \mathrm{~B} \cdot 2 \mathrm{D}=15$ and $6 \mathrm{E} \cdot 5 \mathrm{~B} \cdot 2 \mathrm{D}=13$ in another one. There are 24 stigmatal rows on the left and 26 ones on the right side, with 90 to 100 stigmata in each row; transverse membranes well developed along respective vessels; dorsal languets
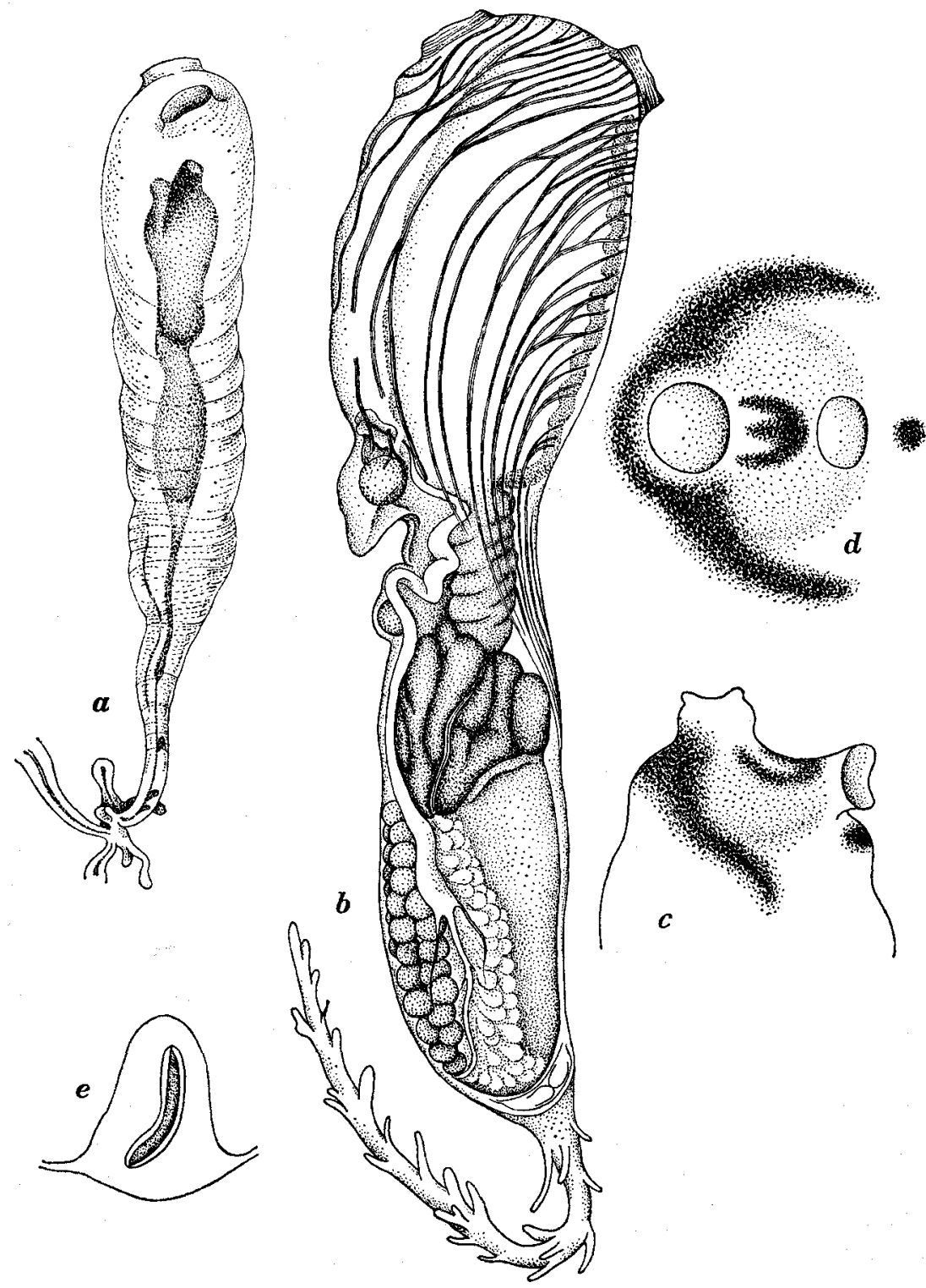

Fig. 3. Clavelina viola n. sp. a, zooid in zooidal test. b, zooid, right side. c, siphonal area, right side. d, the same, front view. e, ciliated groove. 
nearly median. Tentacles are 15 to 20 excluding minute ones, larger and smaller ones partly alternating regularly. The ciliated groove is represented by a longitudinal slit curved slightly. The anus opens at the dorso-posterior corner of the thorax. A backward prominence is definable as the posterior end of the incubatory pouch on the right side of the anal region; up to 23 embryos and fertilized eggs observed in an examined zooid.

The stomach is situated with the pyloric end at the middle of the abdomen and furnished with several distinct plications. As the oesophagus is considerably contracted in examined zooids, the stomach might be sited nearly at the middle when alive. The hind-stomach and the middle intestine are indistinct. The gonads occupy the posterior half of the abdomen posterior to the pyloric end of the stomach; the proximal portion of the vas deferens is running between the testis and the ovary; fully matured ovarian eggs are about $600 \mu$ in diameter.

The larval trunk is 1080 to $1260 \mu$ in length; three attachment processes are supported on the prominent anterior protuberance as usual; two pigment spots of the eye are arranged antero-posteriorly.

Remarks: The present form is related closely to $C$. coerulea Oka in that respective zooids are isseued strictly separately from the stolon. However, the former differs from the latter very clearly in the feature of the thoracic musculature. In coerulea, $\mathbf{E}$ is incomparably larger and a few atrial muscles are running posteriorly across usual muscles. Moreover, the ciliated groove is transverse in coerulea. The thoracic musculature of the present form resembles superficially those of C. elegans (Oka) and C. cyclus Tokioka and Nishikawa, but $\mathrm{E} / \mathrm{B}$ is evidently larger in the present form; for instance $\mathrm{B} \geqq \mathrm{E}$ in elegans or clearly $\mathrm{B}>\mathrm{E}$ in cyclus. In addition to this, in elegans and cyclus zooids are issued from the common basal mass of the test. Larger $\mathrm{E}$ in the present form reminds us of $C$. miniata Watanabe and Tokioka and C. molluccensis (Sluiter), but in these two species the stomach is located much more posteriorly and the colouration of live specimens is quite different; in addition zooids are issued from the common basal mass in molluccensis. After all, the present colony is considered to represent a new species that is named viola according to its colouration when alive.

\section{Clavelina molluccensis (Sluiter, 1904)}

(Fig. 4)

Millar (1975): Steenstrupia, vol. 3, no. 20, 211-212, figs. 6 a-e. For other synonyms see Tokioka (1967, p. 104).

Material: A single colony collected by Yanagisawa at Miyanohama of Titizima Island of the Bonin (= Ogasawara) Islands on April 10, 1974.

Colony: Nine zooids are issued from the common basal mass about $5 \mathrm{~mm}$ in thickness. The test is gelatinous, colourless and transparent in the distal half of the zooidal test, but less transparent and much wrinkled and sometimes fouled with thecatan hydrozoans in the proximal half; soft throughout the whole zooidal test. 
Zooid: Zooids are 13 to $18 \mathrm{~mm}$ long and 7 to $9 \mathrm{~mm}$ wide; the thorax is shorter than the abdomen. A purplish tint still remains on the thorax two years after the preservation in 10\% solution of formalin; no record of the colouration of the live specimen is available. Both apertures open on the top of distinct but short siphons and with a plain margin. The thoracic musculature consists of about a dozen of longitudinal muscles; the formula is $6 \mathrm{E} \cdot 4-5 \mathrm{~B} \cdot 1-2 \mathrm{D}=12$. Twenty-six (in a $15 \mathrm{~mm}$ long zooid) to
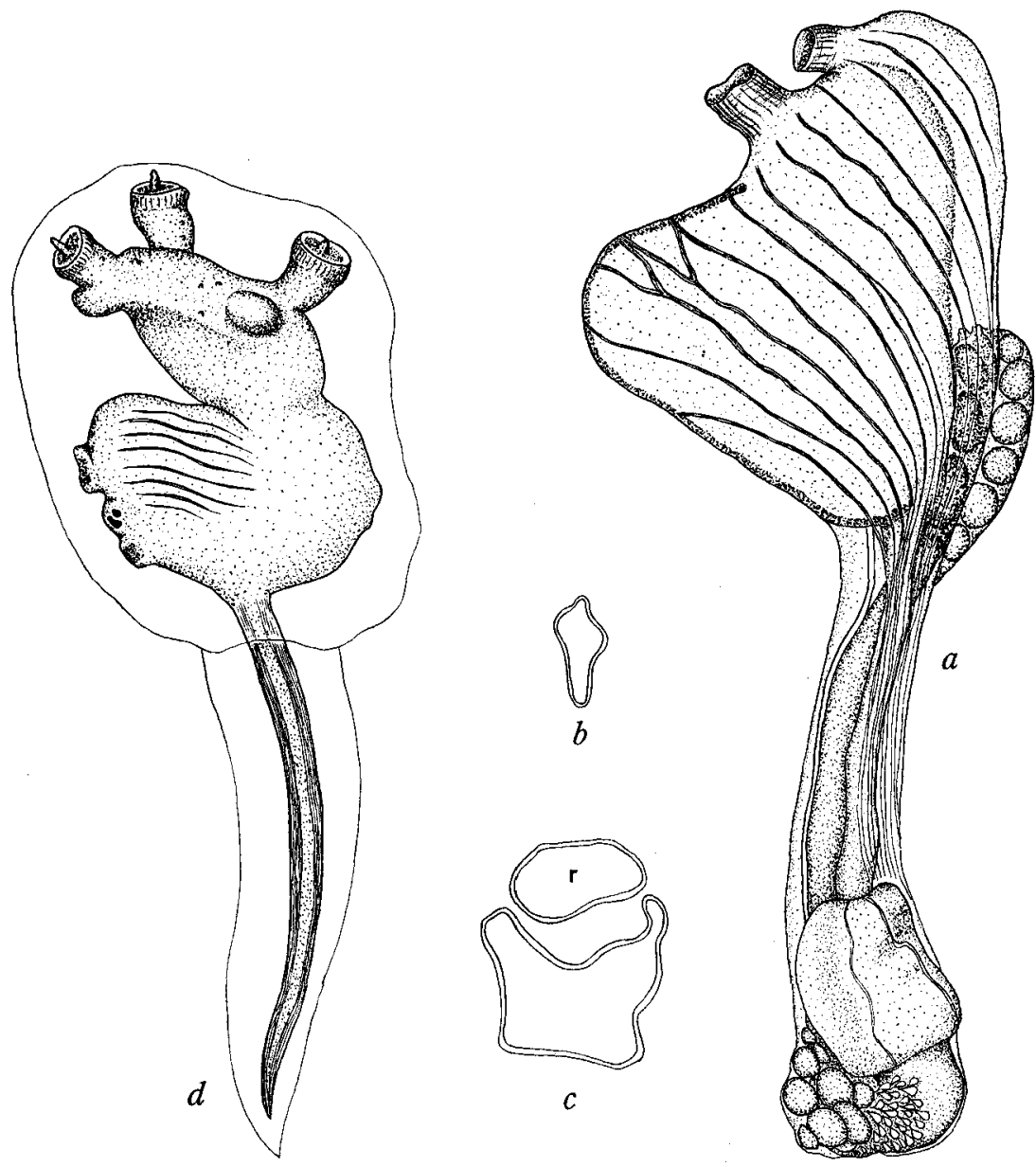

Fig. 4. Clavelina molluccensis (Sluiter). a, zooid, left side. b, ciliated groove. c, section of stomach. d, larva.

33 (in the biggest zooid $18 \mathrm{~mm}$ in length) stigmatal rows; each containing 60 to 70 stigmata. A distinct incubatory pouch is extending posteriorly from the right dorsoposterior part of the thorax to the anterior third or fifth of the abdomen; up to a dozen of embryos and fertilized eggs are included in examined zooids. Tentacles about a dozen; larger and smaller ones alternating nearly regularly and six larger ones 
situated posterior to the ring of smaller ones. The ciliated groove is represented by a longitudinally elongate elliptical opening.

The stomach is situated near the posterior end of the abdomen, with the cardiac end approximately at the posterior third of the abdomen, and the wall is folded distinctly; nearly square in section. Ovarian eggs up to $600 \mu$ in diameter.

Larva: Embryos developed in the incubatory pouch attain 900 to $1300 \mu$ in length. Three attachment processes are supported on the large anterior protuberance as usual. Respective processes are accompanied with a prominent process at the base (Fig. 4, d) as recently illustrated by Millar (1975, $6 \mathrm{e}$ ). Both the attachment processes and the anterior protuberance are furnished sparsely with small papillae. A remarkably high central cone of secretory cells is formed already in the anterior cup of each attachment process in the $1600 \mu$ long larva, but still low and indistinct in the $1300 \mu$ long embryo. The tail is as long as the trunk in the $1600 \mu$ long larva.

Remarks: A great variability in the shape of the colony in this species was noted far ago by Van Name (1918). The appearance of the colony of the present specimen is similar to that of the colony from Cape Beileau described by Hastings (1931, p. 829; pl. I, fig. F). As noted already by many authors, the colouration of the thoracic mantle of live specimens is quite unique. A purplish tint observed on the thoracic mantle of the present specimen may be the remain of the characteristic colouration, though it is impossible to confirm the existence of the yellow pigmentation in the present specimen. The extremely posterior situation of the stomach in the present specimen conforms well to that referred to by Sluiter (1895, fig. 3) in the specimen from Amboina, by Tokioka (1967, fig. 35 c) in the specimen from the Palau Islands and by Millar (1975, fig. 6 c) in the specimen from the Philippines. Further, the formula of the thoracic muscles in the present specimen resembles closely that illustrated by Tokioka (1967, fig. 6 c) and Millar (1975, fig. 6 c), though a considerable variability in the number of thoracic muscles has been noted by Van Name (1918) and Tokioka (1967).

The folded wall of the stomach in the present specimen agrees well with the description of the stomach made by Tokioka (1967), as "-with four longitudinal ridges including typhlosole" (p. 106), though in the specimens treated by other authors the stomach surface is described as smoothly walled and actually some of them were ever attributed to the genus Podoclavella. As to this point, refer to the note given by Nishikawa and Tokioka (1976).

The stigmatal rows are a little more abundant in the present specimen than in the specimens from other localities; this is more pronounced when the number is read against the size of zooids. About 25 rows are recorded in a $70 \mathrm{~mm}$ (?) long zooid by Van Name (1918) and 15-16 rows in a $15 \mathrm{~mm}$ long zooid and 22-29 rows in 23-24 $\mathrm{mm}$ long zooids by some other authors. However, this differance may be safely regarded to be included in the intraspecific variation.

In the Sluiter's description of Clavelina (Podoclavella) meridionalis Herdman from Amboina, that is regarded generally as the original description of his molluccensis, 
seemingly several incubatory pouches are noted and shown in both the thorax and the abdomen, but mainly in the latter (1895; pl. 6, figs. 2 and 3 ). However, it is very possible that the pouches in the abdomen are nothing but only the clusters of mature eggs on the way from the ovary to the proper incubatory pouch in the thorax, markedly protruded out by strong contraction.

\section{LITERATURE}

Hastings, A.B. 1931. Tunicata. Great Barrier Reef Exped., Sci. Rep., vol. 4, no, 3, pp. 69-110, text-figs. 1-17, pls. 1-3.

Millar, R.H. 1975. Ascidians from the Indo-West-Pacific region in the Zoological Museum, Copenhagen. Stcenstrupia, vol. 3, pp. 205-336, 108 text-figs.

Nishikawa, T. and Tokioka, T. 1976. Contributions to Japanese ascidian fauna. XXIX. Notes on some clavelinids from the Japanese waters. Publ. Seto Mar. Biol. Lab., vol. 23, nos. 1/2, pp. 6382,7 text-figs., 1 pl.

Pizon, A. 1908. Ascidies d'Amboine. Rev. Suisse Zool., vol. 16, pp. 195-240, pls. 9-14.

Sluiter, C.P. 1895. Tunicaten. In Semon, R., Zoologische Forschungsreisen in Australien und den malayishen Archipel. Denkschr. Gesell., vol. 8, pp. 163-186, pls. 6-10.

- 1904. Die Tunicaten der Siboga-Expedition. I Abt. Die socialen und holosomen Ascidien. Siboga-Exped., Monogr. 56a, 126 pp., 15 pls.

Tokioka, T. 1967. Pacific tunicata of the United States National Museum. U.S. National Mus. Bull., 100, 247 pp., 105 text-figs.

For other literature see Nishikawa and Tokioka (1976). 